\title{
Identification of a gene from Streptomyces rimosus M527 negatively affecting antibiotic biosynthesis and morphological differentiation
}

\section{Zheng Ma}

China Jiliang University

\section{Zhangqing Song}

China Jiliang University

Jie Xu

China Jiliang University

Andreas Bechthold

Albert-Ludwigs-Universitat Freiburg

Xiaoping Yu ( $\nabla$ yuxiaoping19630306@163.com )

China Jiliang University https://orcid.org/0000-0002-1775-6467

\section{Research}

Keywords: NsdAsr, Streptomyces rimosus, Rimocidin, CRISPR/Cas9

Posted Date: March 18th, 2020

DOl: https://doi.org/10.21203/rs.3.rs-17670/v1

License: (9) This work is licensed under a Creative Commons Attribution 4.0 International License. Read Full License 


\section{Abstract}

Background: The polyene macrolide rimocidin, produced by Streptomyces rimosus M527, was found to be highly effective against a broad range of fungal plant pathogens. Current understanding of the regulatory mechanism of rimocidin biosynthesis and morphological differentiation in S. rimosus M527 is limited. NsdA is considered as a negative regulator involved in morphological differentiation and biosynthesis of secondary metabolites in some Streptomyces.

Results: In this study, $n s d A_{s r}$ was cloned from S. rimosus M527. The role of $n s d A_{s r}$ in rimocidin biosynthesis and morphological differentiation was investigated by gene deletion, complementation, and over-expression. A $\Delta \mathrm{nsdA}_{\mathrm{sr}}$ mutant was obtained using CRISPR/Cas9. The mutant produced more rimocidin $(46 \%)$ and generated more spores than the wild-type strain. Over-expression of $n s d A_{s r}$ led to a decrease in rimocidin production and impairment of sporulation. Quantitative reverse transcription-PCR (qRT-PCR) analysis revealed that transcription of rim genes responsible for rimocidin biosynthesis was up-regulated in the $\Delta \mathrm{ndA}_{\mathrm{sr}}$ mutant but down-regulated in the $n s d A_{s r}$ over-expression strain. Similar effects have been described for Streptomyces coelicolor M145 and the industrial toyocamycin-producing strain Streptomyces diastatochromogenes 1628.

Conclusion: $N s d A_{s r}$ is identified as a negative regulator of sporluation and antibiotic biosynthesis as well as the transcription of biosynthetic genes both in its host $S$. rimosus M527 and in model strain $S$. coelicolor and industrial producer strain $S$. diastatochromogenes 1628 . This work will provide further information for understanding regulatory mechanisms controlling rimocidin biosynthesis in S. rimosus M527.

\section{Background}

Streptomyces are Gram-positive bacteria with complex morphological differentiation and secondary metabolism. They are well-known to produce a wide variety of valuable natural products with diverse biological activities [1-3]. In Streptomyces, the processes of morphological differentiation and antibiotic biosynthesis are tightly controlled via multiple levels of regulation that includes cluster-situated, pleiotropic, and global regulators that respond to numerous physiological and environmental conditions [4-6]. Among the many regulatory genes, a gene negatively affecting S Streptomyces differentiation ( $n s d A$ ) was first found in model strain Streptomyces coelicolor A3(2) [7]. The disruption of $n s d A$ in $S$. coelicolor resulted in accelerated sporulation and increased production of three antibiotics, actinorhodin (Act), methylenomycin, and a calcium-dependent antibiotic. Subsequent studies report that $n s d A$ negatively affects antibiotic biosynthesis and morphological differentiation in Streptomyces. For example, in Streptomyces bingchengensis and Streptomyces lydicus A02, disruption of $n s d A$ caused increased production of secondary metabolites (milbemycin A4, nanchangmycin, and natamycin, along with greater production of pigment and spores than their wild-type strain $[8,9]$. 
The tetraene rimocidin is a glycosylated polyketide [10]. Like other macrolides, rimocidin is synthesized in Streptomyces sp. by so-called type I modular polyketide synthases [11]. Because of its broad range of biological activity against pathogenic fungi, rimocidin possessed some potential as a fungicide for controlling plant diseases and became an attractive target for research [12-14]. Streptomyces rimosus M527 (China Center for Type Culture Collection (CCTCC) M2013270), which was originally isolated in 2011 from soil, is also known as rimocidin producer [15]. In 2019, a gene transfer system for the strain was developed [16] and the genome of the strain was sequenced (GenBank accession No. GCA_004196335.1). Recently rimocidin production in the strain could be enhanced by ribosome engineering [17]. Our knowledge about regulatory mechanisms controlling rimocidin biosynthesis and about morphological differentiation lagged far behind our knowledge about the biosynthesis of rimocidin $[11,18,19]$. Elucidation and manipulation of regulatory networks have recently been shown to be an efficient strategy for further improving production of various industrial compounds [20,21]. For example, Luo et al. [22] identified a transcriptional regulator PhaR in Streptomyces roseosporus L30. Deletion of phaR led to an increased expression of the gene cluster resulting in a 6.14-fold increased daptomycin production.

In the genome sequence of $S$. rimosus M527 $n s d A_{s r}$ (GenBank accession No. MN395042) was identified which encodes a protein with high similarity to NsdA from $S$. coelicolor. This study aimed to explore the role of $n s d A_{s r}$ in morphological differentiation and rimocidin biosynthesis in S. rimosus M527. Construction of a mutant of $S$. rimosus $M 527$ with a $n s d A_{s r}$ deletion was accomplished using the CRISPR/Cas9 system. NsdA $A_{s r}$ was identified as a negative regulator of rimocidin biosynthesis by repressing transcription of structural genes. Furthermore, heterologous expression of $n s d A_{s r}$ in Streptomyces diastatochromogenes 1628 and S. coelicolor M145 also affected morphological differentiation and inhibited natural product biosynthesis.

\section{Results}

\section{Cloning and identification of putative $n s d A_{s r}$ from S. rimosus M527}

Referencing the available genome sequence of S. rimosus M527 (GenBank accession No. GCA_004196335.1), a $n s d A$ orthologue $n s d A_{s r}$ gene from S. rimosus M527 was cloned. The nucleotide sequence was submitted to the GenBank database under the accession number MN395042. The $1476 \mathrm{bp}$ $n s d A_{s r}$ gene encodes a protein of 491 amino acids. A phylogenetic tree was constructed to show the relationship between $\mathrm{NsdA}_{\mathrm{sr}}$ and known NsdA homologues in other Streptomyces species (Additional file 1: Figure S1). NsdA ${ }_{s r}$ (boldface) was very similar to known NsdA proteins submitted to National Center for Biotechnology Information (NCBI). Among them, $\mathrm{NsdA}_{\mathrm{sr}}$ showed the highest similarity to NsdA from $S$. griseoflavus (KOG64483, 99.6\% identical amino acids).

\section{Deletion of $n s d A_{s r}$ gene increases rimocidin production and acceleration of sporulation}


To further determine the role of $n s d A_{s r}$ in rimocidin biosynthesis and morphological differentiation, knockout plasmid pWHU2653- $\Delta n s d A_{s r}$ was created (Figure 1A). The construction of the $n s d A_{s r}$ disruption mutant M527- $\Delta$ nsdA $_{\mathrm{sr}}$ was achieved using the CRISPR/Cas9-CodA(sm) combined system. The deletion of $n s d A_{s r}$ was validated by PCR with the corresponding verification primers P5/P8 and P9/P10. As shown in Figure 1B, a $1476 \mathrm{bp} n s d A_{s r}$ gene could be amplified from M527 (lane 1), but not from M527- $\Delta$ nsd $A_{s r}$ (lane 2). In addition, amplicons of $5.7 \mathrm{~kb}$ (lane 3 ) and $4.2 \mathrm{~kb}$ (lane 4) represented products of the wild-type strain M527 and the mutant strain M527- $\Delta \mathrm{nsdA}_{\mathrm{sr}}$. These results indicate that the $n s d A_{s r}$ gene was deleted in mutant M527- $\Delta \mathrm{nsdA}_{\mathrm{sr}}$.

To investigate the effect of the $n s d A_{s r}$ gene on rimocidin production, a shake-flask fermentation experiment was performed using mutant $S$. rimosus $\mathrm{M} 527-\Delta \mathrm{nsdA}_{\mathrm{sr}}$ and wild-type $S$. rimosus $\mathrm{M} 527$. Samples were periodically collected and analyzed to determine the concentration of rimocidin in the fermentation broth using HPLC (Additional file 2: Figure S2). After $96 \mathrm{~h}$, the level of rimocidin produced by S. rimosus $\mathrm{M} 527-\Delta \mathrm{nsdA}_{\mathrm{sr}}$ had reached $318.5 \mathrm{mg} / \mathrm{L}$, an increase of $46 \%$ compared to $S$. rimosus $\mathrm{M} 527$ (Figure 2), suggesting that $\mathrm{NsdA}_{\mathrm{sr}}$ acts as a negative regulator in rimocidin biosynthesis.

To confirm that the deletion of the $n s d A_{s r}$ gene was the sole reason for the increase in rimocidin production, the mutant $\mathrm{M} 527-\Delta \mathrm{nsdA} \mathrm{sr}_{\mathrm{sr}}$ was complemented by introducing an integrative plasmid PSET152:: $n s d A_{s n}$ in which the $n s d A_{s r}$ gene was driven by its own promoter, to generate the complemented strain M527- $\Delta$ nsdA $A_{s r} / p S E T 152:: n s d A_{s r}$. The complemented strain M527-

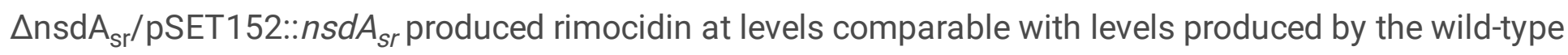
strain (Additional file 2: Figure S2 and Figure 2).

Moreover, to further investigate the effect of $n s d A_{s r}$ on morphological differentiation, scanning electron microscopy (SEM) was employed to examine morphological characteristics of wild-type M527 and mutant M527- $\Delta \mathrm{nsdA}_{\mathrm{sr}}$ strains. More abundant sporulation in mutant M527- $\Delta \mathrm{nsdA}_{\mathrm{sr}}$ was observed (Figure 3). Moreover, no significant difference between S. rimosus M527 and the complemented strain M527-

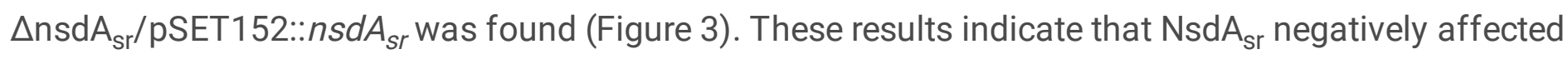
sporulation. In addition, the expression of the empty plasmid pSET152 in S. rimosus M527 had no effect on morphological differentiation or rimocidin production (data not shown).

\section{Construction of recombinant strain S. rimosus $\mathrm{M} 527-\mathrm{NA}_{\mathrm{sr}}$}

$N s d A_{s r}$ was predicted to be a negative regulator, suggesting that an increased copy number of $n s d A_{s r}$ might play a negative role in the morphological differentiation and further depress rimocidin production. The gene $n s d A_{s r}$ was placed under the control of promoter ermE ${ }^{*}$ in plasmid plB139 to create plB139$n s d A_{s r}$ (Additional file 3: Figure S3). The plasmid pIB139- $n s d A_{s r}$ was then introduced into S. rimosus M527 by intergeneric conjugation [16], to generate the recombinant strain S. rimosus M527-NA $\mathrm{sr}_{\mathrm{sr}}$ resistant 
to $300 \mu \mathrm{g} / \mathrm{mL}$ apramycin (Additional file 4: Figure S4). The integration of plasmid pIB139-nsdA $A_{s r}$ into the chromosome of S. rimosus M527 was verified by PCR (Additional file 5: Figure S5).

\section{Over-expression of $n s d A_{s r}$ gene negatively affects sporulation behavior and rimocidin production, and represses transcription of rim genes S. rimosus M527}

Morphological characteristics of the wild-type S. rimosus M527 and the recombinant M527-NA $\mathrm{sr}_{\mathrm{sr}}$ when cultivated on MS agar plates at $28^{\circ} \mathrm{C}$ were assessed. Both S. rimosus M527 and M527-NA sr produced white aerial hyphae, however, a difference in sporulation was observed between both strains (Figure 3 ). The wild-type strain gave rise to abundant yellow spores, whereas the recombinant strain hardly sporulated.

To evaluate the effect of $n s d A_{s r}$ gene on rimocidin production, recombinant strain $S$. rimosus M527-NA ${ }_{s r}$ and control strain S. rimosus M527 were cultured in shake-flask fermentation. As shown in Figure 2, a large decrease in rimocidin production was observed for the recombinant strain M527-NA $\mathrm{sr}$. After $96 \mathrm{~h}$, the amount of rimocidin produced by M527-NA ${ }_{s r}$ reached the highest level of $91.1 \mathrm{mg} / \mathrm{L}$, a $58.2 \%$ decrease in the yield of rimocidin produced by the S. rimosus M527 (218.2 mg/L). These results indicate that $n s d A_{s r}$ negatively affects on $S$. rimosus M527 morphological differentiation and rimocidin biosynthesis. Accordingly, the expression of empty plasmid pIB139 in S. rimosus M527 had no effect on morphological differentiation and rimocidin production (data not shown).

The partial sequence of the rim gene cluster involved in rimocidin biosynthesis in S. rimosus M527 was cloned and published (GenBank accession No: MK300953). The putative functions of $10 \mathrm{rim}$ genes (rimA to rimK) located in the cluster have been analyzed, and these genes are anticipated to be responsible for rimocidin biosynthesis $[11,17]$. To test whether $\mathrm{NsdA}_{\mathrm{sr}}$ regulates rimocidin biosynthesis through affecting transcription of rim genes, we performed qRT-PCR analysis using total RNA of $S$. rimosus M527, mutant M527- $\Delta \mathrm{nsdA}_{\mathrm{sr}}$, complemented strain M527- $\Delta \mathrm{nsdA}_{\mathrm{sr}} / \mathrm{pSET} 152:: n s d A_{s n}$ and S. rimosus M527-NA $\mathrm{s}_{s r}$ after 48 and $84 \mathrm{~h}$ of fermentation. As compared with wild-type, transcriptional levels of rim genes were obviously increased in M527- $\Delta \mathrm{ndA}_{\mathrm{sr}}$, and the increase was diminished in the complemented strain. Transcriptional levels of rim genes were repressed in strain S. rimosus M527-NA $\mathrm{sr}_{\mathrm{sr}}$ (Figure 4). NsdA $\mathrm{sr}_{\mathrm{sr}}$ thus impairs gene expression at the transcriptional level for all rim genes and further decreases rimocidin production in over-expressing recombinant strains.

\section{Heterologous expression of the $n s d A_{s r}$ gene negatively affects sporulation behavior and antibiotic production of S. coelicolor M145 and S. diastatochromogenes 1628}

To determine whether the $n s d A_{s r}$ has similar negative effects on $S$. coelicolor M145 and $S$. diastatochromogenes 1628 , the plasmid pIB139-nsd $A_{s r}$ was also introduced into $S$. coelicolor M145 and S. diastatochromogenes 1628 by intergeneric conjugation, to generate the recombinant strains M145$\mathrm{NA}_{\mathrm{sr}}$ and $1628-\mathrm{NA}_{\mathrm{sr}}$, both resistant to $50 \mu \mathrm{g} / \mathrm{mL}$ apramycin (data not shown). The integration of plasmid 
pIB139-nsd $A_{s r}$ into the chromosome of $S$. coelicolorM145 (Additional file 6: Figure S6) and $S$. diastatochromogenes 1628 (Additional file 7: Figure S7) was verified by PCR, respectively. When grown on Gauze's No. 1 medium for 6 days, blue pigment corresponding to Act, which diffuses into the agar, can be detected earlier and is increased in wild-type $S$. coelicolor M145 comparing with the recombinant strain $\mathrm{M} 145-\mathrm{NA} \mathrm{Ar}_{\mathrm{sr}}$ (Figure 5A). Sporulation behaviors of $S$. coelicolor M145-NA $\mathrm{sr}_{\mathrm{rr}}$ was also delayed because of the introduction of the $n s d A_{s r}$ gene. Similarly, heterologous expression of the $n s d A_{s r}$ gene had negative effects on sporulation and toyocamycin(TM) production of $S$. diastatochromogenes 1628 . Nearly no difference between control strain $S$. diastatochromogenes 1628 and $S$. diastatochromogenes 1628-NA ${ }_{\text {sr }}$ in terms of cell growth was observed (Figure 5B). However, after $24 \mathrm{~h}$ of cultivation, the sporulation of $S$. diastatochromogenes 1628-NA $\mathrm{sr}_{\mathrm{sr}}$ was obviously impaired. TM production for $S$. diastatochromogenes $1628-\mathrm{NA}_{\mathrm{sr}}$ was greatly reduced (Figure $5 \mathrm{C}$ ). After $84 \mathrm{~h}$, TM production by $1628-\mathrm{NA}_{\mathrm{sr}}$ was reduced by $52 \%$.

Additionally, the effect of $n s d A_{s r}$ on the transcription of the respective genes involved in biosynthesis of Act and TM was investigated. In S. coelicolor, Act biosynthesis is dependent on the transcriptional activation of the Act biosynthesis cluster by the Actll-orf4 protein, and increased expression of actIl-orf4 results in the overproduction of Act [23-26]. Total RNA from S. coelicolor M145 and M145-NA $\mathrm{sr}$ was isolated after 48 and $84 \mathrm{~h}$ of cultivation. Semi-quantitative RT-PCR analysis results indicated that gene actll-orf4 was down-regulated in S. coelicolor M145-NA $\mathrm{sr}_{\mathrm{sr}}$ (Figure 6A), indicating that heterologous expression of $n s d A_{s r}$ weakens transcription of actll-orf4. As an internal control, the expression of $16 \mathrm{~S}$ rDNA was comparable in the two strains.

As expected, semi-quantitative RT-PCR analysis also indicated that heterologous expression of $n s d A_{s r}$ had similar negative effects on the transcription of five toy genes (toy $A$, toy $B$, toy $E$, toy $F$, and toy $G$ ). Compared to the wild-type strain, the transcriptional levels of all toy genes were greatly decreased in $1628-\mathrm{NA}_{\mathrm{sr}}$ (Figure 6B).

\section{Discussion}

The polyene macrolide rimocidin shows strong antifungal activity and can be used to treat plant fungal diseases. S. rimosus M527 is a rimocidin producer, but its rimocidin production is very limited. Accordingly, significant focus has been placed on developing genetic transformation methods and expression systems [16] or ribosome engineering technology combined with new fermentation conditions to improve rimocidin production [17]. The long-term goal of our research is to better understand regulatory mechanisms involved in rimocidin biosynthesis. Such understanding will allow rational modification of regulatory networks to achieve up- or down-expression of specific gene(s) to control the desired metabolic flow. This will eventually lead to an increased rimocidin production and more potent and useful rimocidin analogues. To date, a lack of knowledge of the regulation of rimocidin biosynthesis has prevented titer enhancement of rimocidin production by rational strategies. 
The $n s d A$ gene, which is found and conserved in some Streptomyces, negatively affects morphological differentiation and secondary metabolite production [7-9]. Recently, by genome mining of $S$. rimosus M527, the $n s d A$ homologue $n s d A_{s r}$ was found, which encodes a 491-amino-acid protein that shares up to $75 \%$ amino acids with other NsdA proteins. An obvious question is whether $n s d A_{s r}$ has similar effects on sporulation behavior and rimocidin production.

An efficient gene disruption technology in S. rimosus M527 will make it possible to determine gene function through characterization of deletion mutant phenotypes. And it will certainly contribute to a better understanding of the relationship between regulators and rimocidin biosynthesis. Unfortunately, biotechnological methods available in Streptomyces are limited. Typically, for gene disruption in Streptomyces, single crossover integration of a suicide plasmid can be employed, resulting in disruption of the gene of interest with a selectable marker [27]. However, the limited number of selectable markers limits the reusability of this approach. Alternatively, clean genomic deletions can be made via doublecrossover integration. However, this multistep process is often time-consuming and laborious [27-29]. Auspiciously, the appearance of clustered regularly interspaced short palindromic repeats (CRISPR)/CRISPR -associated (Cas) protein systems provides an ideal solution to these problems. Compared with traditional methods, the application of CRISPR/Cas9 has several advantages, including higher efficiency and ease of operation [30]. The establishment of CRISPR/Cas9-based genetic manipulation approaches in Streptomyces opened a new era for genome engineering of this type of microorganism [31]. A few CRISPR/Cas9 systems for genome editing have been developed and applied in various Streptomyces species, such as Streptomyces coelicolor [32] and Streptomyces lividans [33]. By co-expression with customized single guide RNAs (sgRNAs), Streptococcus pyogenes Cas9 nuclease can mediate a double-strand break in the sgRNA binding region; efficient double crossover can be achieved when the homologous templates are provided in the same plasmid. Among them, pWHU2653, based on engineered CRISPR/Cas9 combined with the counter selection system CodA(sm), has been developed and was successfully used to rapidly and effectively delete the Act polyketide chain length factor gene actl-ORF2 [34]. In this study, in order to clarify the relationship of $n s d A_{s r}$ to morphological differentiation and rimocidin biosynthesis in S. rimosus M527, pWHU2653 was adopted for the construction of a $n s d A_{s r}$ deletion mutant using CRISPR/Cas9 system. Results show that gene deletion of $n s d A_{s r}$ results in an increase in rimocidin production. Complementation of $n s d A_{s r}$ reduced rimocidin production to levels comparable with production in the wild-type strain. qRT-PCR analysis revealed that rim genes were upregulated in the $n s d A_{s r}$ mutant and down-regulated in the $n s d A_{s r}$ over-expression strain. In addition, deletion and over-expression of $n s d A_{s r}$ led to acceleration and delaying of sporulation, respectively. The qRT-PCR result demonstrated that the decreased rimocidin production caused by the introduction of $n s d A_{s r}$ was attributed to the inhibition of transcription of rimocidin biosynthetic genes. These results support the conclusion that $\mathrm{NsdA}_{\mathrm{sr}}$ plays a negative role in morphological differentiation and rimocidin production in S. rimosus M527.

Whether the negative effect of $\mathrm{NsdA}_{\mathrm{sr}}$ is universal to other Streptomyces is still unknown. In this study, the deduced amino acid sequence of $\mathrm{NsdA}_{\mathrm{sr}}$ showed $77.6 \%$ similarity to $\mathrm{NsdA}$ sc from model strain $S$. 
coelicolor. The disruption of the $n s d A_{s c}$ gene resulted in the overproduction of Act in $S$. coelicolor. Thus, the heterologous expression of $n s d A_{s r}$ in $S$. coelicolor was considered and performed. As expected, $\mathrm{NsdA}_{\mathrm{sr}}$ had negative effects on sporulation and Act biosynthesis as well as on transcription of the pathway-specific regulator, actIl-orf4. This result confirmed that $\mathrm{NsdA}_{\mathrm{sr}}$ is not only a homologue of $\mathrm{NsdA}_{\mathrm{sc}}$ but also has similar effects. Subsequently, by heterologous expression of $n s d A_{s n}$ similar negative effects on morphological differentiation and antibiotic production were observed in $S$. diastatochromogenes 1628 , which is considered a significant industrial producer of the nucleoside antibiotic, TM $[35,36]$.

\section{Conclusions}

In conclusion, $n s d A_{s r}$ cloned in this study is identified as a negative regulator of sporluation and antibiotic biosynthesis as well as the transcription of biosynthetic genes both in its host $S$. rimosus M527 and in model strain S. coelicolor and industrial producer strain S. diastatochromogenes 1628 . However, the exact molecular mechanism of rimocidin biosynthesis and other metabolic pathways affected by $\mathrm{NsdA}_{\mathrm{sr}}$ remains unknown. This point could be elucidated by RNA-seq or -omics strategies using the $n s d A_{s r}$ deletion mutant and wild-type strains. Further studies are needed to elucidate other key genes or metabolic pathways involved in rimocidin biosynthesis.

The importance of this work is that it provides further information for understanding regulatory mechanisms controlling rimocidin biosynthesis in S. rimosus M527. In addition, the successful application of a CRISPR/Cas9 system based on pWHU2653 in this study will provide a basis for efficient genome manipulation for the overproduction of rimocidin.

\section{Materials And Methods}

\section{Materials}

Q5 High-Fidelity Master Mix with GC-buffer was purchased from NEB. Restriction endonucleases, Miniprep, and Gel Extraction kits were purchased from TaKaRa Biotechnology Co. Ltd. 5-Fluorocytosine (5FC) was purchased from Aladdin. Oligonucleotide primer synthesis and DNA sequencing of PCR products were performed by Shanghai Sunny Biotechnology Co. Ltd. China.

\section{Strains, plasmids, and primers}

The strains and plasmids used in this study are listed in Table 1. Strains were used as follows: Rimocidin producer S. rimosus M527 has been deposited in the China Center for Type Culture Collection (CCTCC: M2013270). Act producer S. coelicolor M145 was provided by Prof. Andreas Bechthold (University of Freiburg, Freiburg, Germany). TM producer S. diastatochromogenes 1628 has been deposited in the China General Microbiological Culture Collection Center (CGMCC No. 2060) [37]. Escherichia coli JM109 was used as a general host for gene cloning and plasmid construction. Methylation-deficient strain, E. coli 
ET12567/pUZ8002, was used as the donor for plasmid transfer to Streptomyces by intergeneric conjugation.

Table 1 Strains and plasmids used in this study 
Strain

\begin{tabular}{|c|c|c|}
\hline E. coli JM109 & General cloning host & Our lab \\
\hline E. coli ET12567/pUZ8002 & $C m^{r}, K m^{r}$, donor strain for conjugation & Our lab \\
\hline S. rimosus M527 & Rimocidin producer & $\begin{array}{l}\text { CCTCC } \\
2013270\end{array}$ \\
\hline $\begin{array}{l}\text { S. diastatochromogenes } \\
1628\end{array}$ & Toyocamycin producer & $\begin{array}{l}\text { CGMCC } \\
2060\end{array}$ \\
\hline S. coelicolor M145 & Actinorhodin producer & $\begin{array}{l}\text { Prof. } \\
\text { Andreas }\end{array}$ \\
\hline M527- $\Delta n s d A_{s r}$ & $n s d A_{s r}$ gene deletion mutant, derived from M527 strain & $\begin{array}{l}\text { This } \\
\text { work }\end{array}$ \\
\hline $\begin{array}{l}\text { M527- } \\
\Delta \text { nsdA }_{\text {sr }} / \text { pSET152::nsdA }\end{array}$ & $\begin{array}{l}n s d A_{s r} \text { complemented strain, mutant M527- } \Delta n s d A_{s r} \text { with } \\
\text { integrative plasmid pSET152::nsdA } A_{s r}\end{array}$ & $\begin{array}{l}\text { This } \\
\text { work }\end{array}$ \\
\hline M527-NA & M527 with integrative vector plB139-nsd $A_{s r}$ & $\begin{array}{l}\text { This } \\
\text { work }\end{array}$ \\
\hline $\mathrm{M} 145-\mathrm{NA}$ sr & M145 with integrative vector pIB139-nsdA $A_{s r}$ & $\begin{array}{l}\text { This } \\
\text { work }\end{array}$ \\
\hline $1628-\mathrm{NA}_{\mathrm{sr}}$ & 1628 with integrative vector pIB139-nsd $A_{s r}$ & $\begin{array}{l}\text { This } \\
\text { work }\end{array}$ \\
\hline
\end{tabular}

Plasmids

PSET152

Integrative plasmid, apr', oriT $T_{\mathrm{RK} 2}, \varphi \mathrm{C} 31 \mathrm{int} / \mathrm{attP}$

Our lab

plB139

Derivative of integrative plasmid pSET152, harboring a

Our lab

PermE $E^{*}$ promoter, apr ${ }^{r}$, orit $T_{\mathrm{RK} 2}, \varphi \mathrm{C} 31 \mathrm{int} / \mathrm{attP}$

pWHU2653

Scas9, sgRNA cloning cassette, $\operatorname{cod} A(s m), a p r^{r}$, ori(coEl)

$\mathrm{pWHU2653- \triangle nsdA_{sr }}$

Derived from pWHU2653, for deletion of $n s d A_{s n}$ containing up- and down-stream homologous arms of $n s d A_{s r}$

This work

pSET152::nsdA

Derived from pSET152, harboring $n s d A_{s r}$ driven by its own promoter

This work

plB139-nsd $A_{s r}$ $n s d A_{s r}$ gene under the control of promoter PermE $E^{\star}$ in pIB139

This work 
Plasmid pWHU2653 [34], a gift from Prof. Sun YH, was used for disruption of the $n s d A_{s r}$ gene using the CRISPR/Cas9 system. The primers (restriction sites are underlined) used in this study are listed in Table 2.

\section{Table 2 Primers used in this study}

Primers Description Source or reference

\begin{tabular}{|c|c|c|}
\hline P1 & 5'-CACCACCACCACTGAGCTAGCTTCAGACGTGTCTA-3' & This work \\
\hline P2 & 5'-TCCGTGTCCGGCGTCGACCTGCTGGATCCT-3' & This work \\
\hline P3 & 5'-AGGTCGACGCCGGACACGGAGTTTTAGAGC-3' & This work \\
\hline P4 & 5'-GTCGACTAGAGGATCCCCGGGTATCTAGAAA-3' & This work \\
\hline P5 & $\begin{array}{l}\text { 5'-CGTCGACCTGCAGGCATGCAAGCTTCGCGTCGTCCACCAGCACCTCG- } \\
3^{\prime}\end{array}$ & This work \\
\hline P6 & 5'-AATCGGAATGGGGGCGTTCCACAGCACTCCCACAGACCCCGG-3' & This work \\
\hline P7 & 5'-GGTCTGTGGGAGTGCTGTGGAACGCCCCCATTCCGATTGC-3' & This work \\
\hline P8 & $\begin{array}{l}\text { 5'- } \\
\text { GAGTGCTTGCGGCAGCGTGAAGCTTGGCATGGTCGGCCTTACGGACAG- } \\
3^{\prime}\end{array}$ & This work \\
\hline P9 & 5'-ACCGEATATGGTGGGCGGCAGTGGCGGCAC-3' (Ndel) & This work \\
\hline P10 & 5'-ACCGTCTAGATTATCAGACGGCCTCCGCGCCGG-3' (Xbal) & This work \\
\hline P11 & 5'-ACCGCATATGCGGCAGCCGGACCGAGCAGT-3' (Ndel) & This work \\
\hline
\end{tabular}

Primers P1-P4 were used for amplification of sgRNA. Primers P5 and P6 were used for amplification of up-stream homologous arms of $n s d A_{s r}$. Primers P7 and P8 were used for amplification of down-stream homologous arms of $n s d A_{s r}$ Primers P9 and P10 were used for amplification of $n s d A_{s r} N d e l$ and $X b a l$ restriction enzyme sites are underlined. Primers $\mathrm{P} 11$ and $\mathrm{P} 10$ were used for amplification of a 1776-bp DNA fragment containing the coding region of $n s d A_{s r}$ and its 300-bp upstream promoter region.

\section{Media and culture conditions}

E. coli strains were cultured using liquid or solid LB medium containing appropriate antibiotics at $37^{\circ} \mathrm{C}$. Antibiotics were used in the following concentrations: apramycin $(100 \mu \mathrm{g} / \mathrm{mL})$, chloramphenicol $(25 \mu \mathrm{g} / \mathrm{mL})$, ampicillin $(100 \mu \mathrm{g} / \mathrm{mL})$, and kanamycin $(50 \mu \mathrm{g} / \mathrm{mL})$. To generate spores, Streptomyces cells were sprayed on MS medium [17] and incubated for $5-6$ days at $28^{\circ} \mathrm{C}$. Collected spores were washed with water and preserved in water/glycerol $(1: 1, \mathrm{v} / \mathrm{v})$ at $-80^{\circ} \mathrm{C}$. 
2CMC solid medium [16] was used for conjugation. CP liquid medium [38] was used as seed medium. MS, YMG [39], and Gauze's No. 1 medium were used for morphological observation. Gauze's No. 1

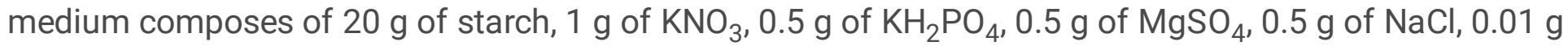
of $\mathrm{FeSO}_{4}$, and $20 \mathrm{~g}$ of agar per liter.

S. rimosus M527 and its derivates were incubated using the method of Zhao et al. [17]. S. diastatochromogenes 1628 and its derivative were incubated using the method of Xu et al. [35]. $S$. coelicolor M145 and its derivative were incubated using the method of Zhao et al. [38].

\section{Construction of the $\Delta \mathrm{nsdA} \mathrm{sr}_{\mathrm{sr}}$ mutant and its complementation}

Plasmid pWHU2653, a delivery vector containing the sgRNA cloning cassette and counterselection marker CodA(sm), was developed for genome editing in Streptomyces using the CRISPR/Cas9 system $[34,40]$. sgRNA consists of an exchangeable $20 \mathrm{nt}$ guide sequence that matches the target DNA and an invariant scaffold that binds to Cas9 in pWHU2653. In this study, a protospacer adjacent motif (PAM) for sgRNA and a $20 \mathrm{nt}$ target guide sequence AGGTCGACGCCGGACACGGA of the $n s d A_{s r}$ gene extended by PAM were selected according to the guide design tool (https://zlab.bio/guide-design-resources). To construct the double-enzyme digestion sgRNA cloning cassette, PCR was used to generate the sgRNA with the target sequence using pWHU2653 as the template. Primers P1/P2 were used to amplify the upstream fragment, whereas another pair of primers P3/P4 were used to amplify the downstream fragment. The two fragments, each end flanked by a 20 bp homology sequence from pWHU2653, were spliced together by overlap extension PCR, yielding a $0.3 \mathrm{~kb}$ sgRNA fragment in which expression of sgRNA is under control of the constitutive promoter ermE ${ }^{*}$. The $0.3 \mathrm{~kb}$ sgRNA cloning cassette was inserted into pWHU2653 between Nhel/ Xbal using an infusion cloning kit, generating plasmid pWHU2653-sgRNA. Subsequently, the $2.1 \mathrm{~kb}$ upstream homologous arm (UHA) and $2.1 \mathrm{~kb}$ downstream homologous arm (DHA) of the $n s d A_{s r}$ start codon were amplified by primer pairs P5/P6 and P7/P8 from genomic DNA of $S$. rimosus M527, respectively. The resulting DNA fragments, UHA and DHA, were ligated into the Hindlll site of pWHU2653-sgRNA using Gibson assembly methods as described by Gibson et al. [41], yielding plasmid pWHU2653- $\Delta n s d A_{s r}$ for gene knock out.

The constructed pWHU2653- $\Delta n s d A_{s r}$ was introduced into the wild-type strain $S$. rimosus M527 by intergeneric conjugation as described by Song et al. [16]. Single apramycin-resistant exconjugants were patched on $2 \mathrm{CMC}$ agar, containing apramycin and nalidixic acid (300 and $100 \mu \mathrm{g} / \mathrm{mL}$, respectively), and grown at $28{ }^{\circ} \mathrm{C}$ for four or five generations. Genomic DNA was extracted from mycelium grown on the plate and amplified by PCR using primers P9/P10 to verify the deletion of $n s d A_{s r}$. To obtain plasmid-free progeny, single exconjugants were picked and streaked on $2 \mathrm{CMC}$ agar containing $800 \mu \mathrm{g} / \mathrm{mL} 5 \mathrm{FC}$ and grown in the dark at $28^{\circ} \mathrm{C}$ for 3 or 4 days. The $5 \mathrm{FC}^{\mathrm{R}}$ colonies were then replicated to $2 \mathrm{CMC}$ with and without apramycin to confirm plasmid loss. The $\Delta \mathrm{nsdA}_{\mathrm{sr}}$ mutants were named S. rimosus M527- $\Delta \mathrm{nsd} \mathrm{A}_{\mathrm{sr}}$. 
For complementation of $n s d A_{s r}$ in S. rimosus M527- $\Delta n s d A_{s r}$, a 1776 bp DNA fragment containing the coding region of $n s d A_{s r}$ and its 300 bp upstream promoter region was amplified by PCR using P11 and P10 as primers. The DNA fragment was inserted into the Ndel and Xbal sites of pSET152 to obtain PSET152::nsd $A_{s r}$ Introduction of pSET152::nsd $A_{s r}$ and the empty vector pSET152 as a control into mutant M527- $\triangle \mathrm{nsdA}_{\mathrm{sr}}$ by conjugation resulted in the complemented strain $S$. rimosus M527$\Delta \mathrm{nsdA}_{\mathrm{sr}} / \mathrm{pSET} 152:: n s d A_{s r}$ and the control strain S. rimosus M527- $\Delta \mathrm{nsdA}_{\mathrm{sr}} / \mathrm{pSET} 152$, respectively.

\section{Over-expression/Heterologous expression of $n s d A_{s r}$ in $S$. rimosus M527/S. coelicolor M145 and $S$. diastatochromogenes 1628}

All recombinant DNA techniques were performed as described by Sambrook and Russell [42]. Plasmid pIB139 $[43,44]$ is a shuttle vector that replicates in E. coli and integrates site-specifically into Streptomyces chromosomes. Using S. rimosus M527 genomic DNA as a template, a $1476 \mathrm{bp} n s d A_{s r}$ open reading frame (ORF) was amplified by PCR using primers P9 and P10 (Table 1). The PCR product was then digested with Ndel and $X b a l$ and inserted into the corresponding sites of plB139, yielding plasmid pIB139-nsd $A_{s r}$. Sequencing of the inserted gene fragment confirmed that the gene did not contain any mutations.

Subsequently, the introduction of the constructed pIB139-nsd $A_{s r}$ into $S$. rimosus M527, S. coelicolor $\mathrm{M} 145$, and $S$. diastatochromogenes 1628 was conducted by intergeneric conjugation to yield recombinant strains S. rimosus M527-NA ${ }_{\mathrm{sr}}$ S. coelicolor M145-NA $\mathrm{sr}_{\mathrm{sr}}$ and S. diastatochromogenes 1628$N A_{s r}$, respectively. Recombinant strains were confirmed using apramycin resistance and PCR.

\section{Morphological observation}

To evaluate morphological differentiation, wild-type strain $S$. rimosus M527, the $n s d A_{s r}$ disrupted mutant M527- $\Delta \mathrm{nsdA}_{\mathrm{sr}}$, the complemented strain M527- $\Delta \mathrm{nsdA}_{\mathrm{sr}} / \mathrm{pSET} 152:: n s d A_{s n}$ and the recombinant strain M527-NA $\mathrm{sr}_{\mathrm{sr}}$ were streaked on solid MS medium; the wild-type $S$. diastatochromogenes 1628 and recombinant strain 1628-NA $\mathrm{Sr}_{\mathrm{sr}}$ were streaked on solid YMG medium; and the wild-type S. coelicolor M145 and recombinant strain M145-NA $\mathrm{sr}_{\mathrm{sr}}$ were streaked on Gauze's No. 1 medium. The morphology of all strains was observed after incubation for $6-7$ days at $28^{\circ} \mathrm{C}$. Morphological characteristics of the mycelia surface were examined under SEM (JSM-5410LV, JEOL, Tokyo, Japan).

\section{Analysis of gene transcriptional levels by qRT-PCR}

Extraction of RNA and analysis of transcriptional levels of rim genes were performed as described previously $[17,36]$. Extraction of RNA, design of primers, and analysis of the transcription of toy genes were performed as described by Xu et al. [35]. Extraction of RNA, design of primers, and analysis of transcription of actIl-orf4 gene were performed as described by Zhao et al. [38].

\section{Fermentation of antibiotic}


Production of rimocidin by S. rimosus M527 was achieved using the method of Zhao et al. [17]. Production of TM by S. diastatochromogenes 1628 was achieved using the method of Ma et al. [36].

\section{Analysis of antibiotic}

Rimocidin was analyzed using high-performance liquid chromatography (HPLC) (Varian, USA) method described previously [17]. HPLC analysis of TM used the method of Ma et al. [36]. Gauze's No. 1 medium was used to identify the production of Act on agar media by directly evaluating the density of the blue color characteristic of this antibiotic.

\section{Statistical analysis}

All experiments were performed at least three times, and results were expressed as mean \pm standard deviations (SD). Statistical analysis was performed with Student's $t$-test.

\section{Abbreviations}

qRT-PCR: quantitative RT-PCR; TM: toyocamycin; Act: actinorhodin; SEM: scanning electron microscopy; sgRNA: single guide RNA; 5FC:5-Fluorocytosine; CCTCC: China Center for Type Culture Collection; CGMCC: China General Microbiological Culture Collection Center; PAM: protospacer adjacent motif; UHA: upstream homologous arm; DHA: downstream homologous arm; ORF: open reading frame; HPLC: highperformance liquid chromatography; SD: standard deviations. CRISPR/Cas: clustered regularly interspaced short palindromic repeats(CRISPR) /CRISPR-associated

\section{Declarations}

Ethics approval and consent to participate: Not applicable.

Consent for publication: Not applicable.

Availability of data and materials: All data generated or analyzed during this study are included in this published article [and its supplementary information files].

Competing interests: The authors declare that they have no competing interests.

Funding: This work was supported by the National Natural Science Foundation of China (31972320, 31772213), and the excellent youth fund of Zhejiang province, China (LR17C140002).

Authors' contributions: Z Ma designed research wrote this article. ZQ Song and J Xu conducted experiments. A Bechthold revised this article. XP Yu checked the final version. All authors read and approved the manuscript.

Acknowledgments: The authors are grateful to Prof. Yuhui Sun (Wuhan University) for kindly providing the pWHU2653. 


\section{Additional File Information}

Additional file 1: Figure S1. Phylogenetic analysis of $\mathrm{NsdA}_{\mathrm{sr}}$ using NCBI BLASTP.

Additional file 2: Figure S2. HPLC-analysis to measure the influence of $\mathrm{NsdA}_{\mathrm{sr}}$ on rimocidin production.

Additional file 3: Figure S3. Map of constructed plasmid plB139-nsdA $A_{s}$.

Additional file 4: Figure S4. Phenotypic verification of recombinant strains S. rimosus M527-NA $\mathrm{sr}_{\mathrm{s}}$.

Additional file 5: Figure S5. PCR analysis of apramycin ( $\left.a p^{\prime}\right)$ gene from recombinant strains $S$. rimosus M527- $\mathrm{NA}_{\mathrm{sr}}$.

Additional file 6: Figure S6. PCR analysis of apramycin $\left(a p^{\prime}\right)$ gene from recombinant strains $S$. coelicolor $\mathrm{M} 145-\mathrm{NA}$ s.

Additional file 7: Figure S7. PCR analysis of apramycin $\left(a p^{\prime}\right)$ gene from recombinant strains $S$. diastatochromogenes 1628-NA $\mathrm{sr}_{\mathrm{s}}$.

\section{References}

1. Kemung HM, Tan LT, Khan TM, Chan KG, Pusparajah P, Goh BH, Lee LH. Streptomyces as a prominent resource of future anti-MRSA drugs. Front Microbiol. 2018;9:2221.

2. Liu R, Deng Z, Liu T. Streptomyces species: Ideal chassis for natural product discovery and overproduction. Metab Eng. 2018;50:74-84.

3. Olanrewaju OS, Babalola 0O. Streptomyces: implications and interactions in plant growth promotion. Appl Microbiol Biotechnol. 2019;103:1179-88.

4. Martín JF, Ramos A, Liras P. Regulation of geldanamycin biosynthesis by cluster-situated transcription factors and the master regulator PhoP. Antibiotics (Basel). 2019;8. pii: E87.

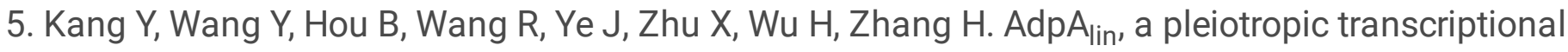
regulator, is involved in the cascade regulation of lincomycin biosynthesis in Streptomyces lincolnensis. Front Microbiol. 2019;10:2428.

6. Hou B, Tao L, Zhu X, Wu W, Guo M, Ye J, Wu H, Zhang H. Global regulator BldA regulates morphological differentiation and lincomycin production in Streptomyces lincolnensis. Appl Microbiol Biotechnol. 2018;102:4101-15.

7. Li W, Ying X, Guo Y, Yu Z, Zhou X, Deng Z, Kieser H, Chater KF, Tao M. Identification of a gene negatively affecting antibiotic production and morphological differentiation in Streptomyces coelicolor A3(2). J Bacteriol. 2006;188:8368-75.

8. Wang XJ, Guo SL, Guo WQ, Xi D, Xiang WS. Role of $n s d A$ in negative regulation of antibiotic production and morphological differentiation in Streptomyces bingchengensis. J Antibiot (Tokyo). 
2009;62:309-13.

9. Wu H, Liu W, Shi L, Si K, Liu T, Dong D, Zhang T, Zhao J, Liu D, Tian Z, Yue Y, Zhang H, Xuelian B, Liang Y. Comparative genomic and regulatory analyses of natamycin production of Streptomyces lydicus Sci Rep. 2017;7:9114.

10. Sowiński P, Pawlak J, Borowski E, Gariboldi P. Stereostructure of rimocidin. J Antibiot (Tokyo). 1995;48:1288-91.

11. Seco EM, Pérez-Zúñiga FJ, Rolón MS, Malpartida F. Starter unit choice determines the production of two tetraene macrolides, rimocidin and CE-108, in Streptomyces diastaticus 108. Chem Biol. 2004;11:357-66.

12. Caffrey P, Aparicio JF, Malpartida F, Zotchev SB. Biosynthetic engineering of polyene macrolides towards generation of improved antifungal and antiparasitic agents. Curr Top Med Chem. 2008;8:639-53.

13. Jeon BJ, Kim JD, Han JW, Kim BS. Antifungal activity of rimocidin and a new rimocidin derivative BU16 produced by Streptomyces mauvecolor BU16 and their effects on pepper anthracnose. J Appl Microbiol. 2016;120:1219-28.

14. Yu J, Liu Q, Chen C, Qi X. Antifungal activity change of Streptomyces rimosus MY02 mediated by confront culture with other microorganism. J Basic Microbiol. 2017;57:276-82.

15. Lu D, Ma Z, Xu X, Yu X. Isolation and identification of biocontrol agent Streptomyces rimosus M527 against Fusarium oxysporumsp. cucumerinum. J Basic Microbiol. 2016;56: 929-33.

16. Song ZQ, Liao ZJ, Hu YF, Ma Z, Bechthold A, Yu XP. Development and optimization of an intergeneric conjugation system and analysis of promoter activity in Streptomyces rimosus J Zhejiang Univ Sci B. 2019;20:891-900.

17. Zhao Y, Song Z, Ma Z, Bechthold A, Yu X. Sequential improvement of rimocidin production in Streptomyces rimosus M527 by introduction of cumulative drug-resistance mutations. J Ind Microbiol Biotechnol. 2019;46:697-708.

18. Escudero L, Al-Refai M, Nieto C, Laatsch H, Malpartida F, Seco EM. New rimocidin/CE-108 derivatives obtained by a crotonyl-CoA carboxylase/reductase gene disruption in Streptomyces diastaticus 108: substrates for the polyene carboxamide synthase PcsA. PLoS One. 2015;10:e0135891.

19. Seco EM, Miranzo D, Nieto C, Malpartida F. The pcsA gene from Streptomyces diastaticus 108 encodes a polyene carboxamide synthase with broad substrate specificity for polyene amides biosynthesis. Appl Microbiol Biotechnol. 2010;85:1797-807.

20. Bednarz B, Kotowska M, Pawlik KJ. Multi-level regulation of coelimycin synthesis in Streptomyces coelicolor A3(2). Appl Microbiol Biotechnol. 2019;103:6423-34.

21. Xia H, Zhan X, Mao XM, Li YQ. The regulatory cascades of antibiotic production in Streptomyces. World J Microbiol Biotechnol. 2020;36:13.

22. Luo S, Chen XA, Mao XM, Li YQ. Transposon-based identification of a negative regulator for the antibiotic hyper-production in Streptomyces. Appl Microbiol Biotechnol. 2018;102:6581-92. 
23. Bruheim P, Sletta H, Bibb MJ, White J, Levine DW. High-yield actinorhodin production in fed-batch culture by a Streptomyces lividans strain overexpressing the pathway-specific activator gene actlORF4. J Ind Microbiol Biotechnol. 2002;28:103-11.

24. Imai Y, Sato S, Tanaka Y, Ochi K, Hosaka T. Lincomycin at subinhibitory concentrations potentiates secondary metabolite production by Streptomyces Appl Environ Microbiol. 2015;81:3869-79.

25. Sohoni SV, Fazio A, Workman CT, Mijakovic I, Lantz AE. Synthetic promoter library for modulation of actinorhodin production in Streptomyces coelicolor A3(2). PLoS One. 2014;9:e99701.

26. Wei J, Tian J, Pan G, Xie J, Bao J, Zhou Z. Development and application of a T7 RNA polymerasedependent expression system for antibiotic production improvement in Streptomyces. Biotechnol Lett. 2017;39:857-64.

27. Kieser T, Bibb MJ, Buttner MJ, Chater KF, Hopwood DA. Practical Streptomyces Norwich: John Innes Centre; 2000.

28. Novakova R, Núñez LE, Homerova D, Knirschova R, Feckova L, Rezuchova B, Sevcikova B, Menéndez $\mathrm{N}$, Morís F, Cortés J, Kormanec J. Increased heterologous production of the antitumoral polyketide mithramycin A by engineered Streptomyces lividans TK24 strains. Appl Microbiol Biotechnol. 2018;102:857-69.

29. Rezuchova B, Homerova D, Sevcikova B, Núñez LE, Novakova R, Feckova L, Skultety L, Cortés J, Kormanec $\mathrm{J}$. An efficient blue-white screening system for markerless deletions and stable integrations in Streptomyces chromosomes based on the blue pigment indigoidine biosynthetic gene bpsA. Appl Microbiol Biotechnol. 2018;102:10231-44.

30. Neldeborg S, Lin L, Stougaard M, Luo Y. Rapid and efficient gene deletion by CRISPR/Cas9. Methods Mol Biol. 2019;1961:233-47.

31. Zhang MM, Wong FT, Wang Y, Luo S, Lim YH, Heng E, Yeo WL, Cobb RE, Enghiad B, Ang EL, Zhao H. CRISPR-Cas9 strategy for activation of silent Streptomyces biosynthetic gene clusters. Nat Chem Biol. 2017. doi: 1038/nchembio.2341.

32. Tong $Y$, Charusanti P, Zhang L, Weber T, Lee SY. CRISPR-Cas 9 based engineering of actinomycetal genomes. ACS Synth Biol. 2015;4:1020-9.

33. Cobb RE, Wang Y, Zhao H. High-efficiency multiplex genome editing of Streptomyces species using an engineered CRISPR/Cas system. ACS Synth Biol. 2015;4:723-8.

34. Zeng H, Wen S, Xu W, He Z, Zhai G, Liu Y, Deng Z, Sun Y. Highly efficient editing of the actinorhodin polyketide chain length factor gene in Streptomyces coelicolor M145 using CRISPR/Cas9-CodA(sm) combined system. Appl Microbiol Biotechnol. 2015;99:10575-85.

35. Xu J, Song Z, Xu X, Ma Z, Bechthold A, Yu X. ToyA, a positive pathway-specific regulator for toyocamycin biosynthesis in Streptomyces diastatochromogenes Appl Microbiol Biotechnol. 2019;103:7071-84.

36. Ma Z, Tao L, Bechthold A, Shentu X, Bian Y, Yu X. Overexpression of ribosome recycling factor is responsible for improvement of nucleotide antibiotic-toyocamycin in Streptomyces diastatochromogenes Appl Microbiol Biotechnol. 2014;98:5051-8. 
37. Ma Z, Liu J, Bechthold A, Tao L, Shentu X, Bian Y, Yu X. Development of intergeneric conjugal gene transfer system in Streptomyces diastatochromogenes 1628 and its application for improvement of toyocamycin production. Curr Microbiol. 2014;68:180-5.

38. Zhao YF, Lu DD, Bechthold A, Ma Z, Yu XP. Impact of otrAexpression on morphological differentiation, actinorhodin production, and resistance to aminoglycosides in Streptomyces coelicolor J Zhejiang Univ Sci B. 2018;19:708-17.

39. Qiu J, Zhuo Y, Zhu D, Zhou X, Zhang L, Bai L, Deng Z. Overexpression of the ABC transporter AvtAB increases avermectin production in Streptomyces avermitilis. Appl Microbiol Biotechnol. 2011;92:337-45.

40. Mo J, Wang S, Zhang W, Li C, Deng Z, Zhang L, Qu X. Efficient editing DNA regions with high sequence identity in actinomycetal genomes by a CRISPR-Cas9 system. Synth Syst Biotechnol. 2019;4:86-91.

41. Gibson DG, Benders GA, Axelrod KC, Zaveri J, Algire MA, Moodie M, Montague MG, Venter JC, Smith HO, Hutchison CA. One-step assembly in yeast of 25 overlapping DNA fragments to form a complete synthetic Mycoplasma genitalium Proc Natl Acad Sci U S A. 2008;105:20404-9.

42. Sambrook J, Russel DW. Molecular cloning: a laboratory manual. New York: Cold Spring Harbor Laboratory; 2001.

43. Wang T, Bai L, Zhu D, Lei X, Liu G, Deng Z, You D. Enhancing macrolide production in Streptomyces by coexpressing three heterologous genes. Enzyme Microb Technol. 2012;50:5-9.

44. Xu X, Wang J, Bechthold A, Ma Z, Yu X. Selection of an efficient promoter and its application in toyocamycin production improvement in Streptomyces diastatochromogenes World J Microbiol Biotechnol. 2017;33:30.

\section{Figures}


$\mathbf{A}$
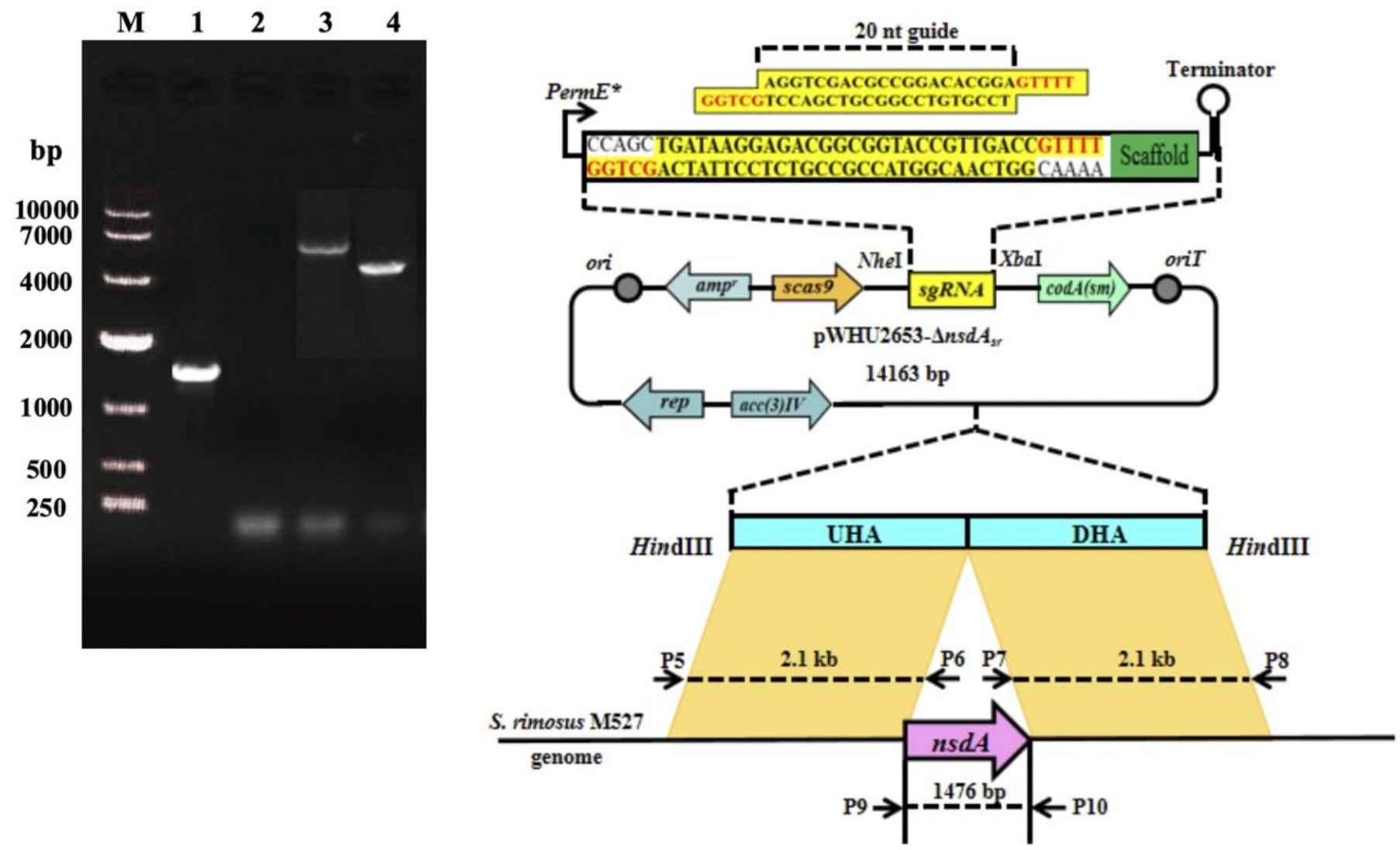

Figure 1

Construction of mutant S. rimosus M527- $\Delta$ nsdAsr. Map of plasmid pWHU2653 $-\Delta$ nsdAsr. A. The sgRNA consists of the $20 \mathrm{nt}$ target gene specific guide sequence of S. rimosus M527 (yellow) and the invariant scaffold RNA (green). Light orange parallelograms connect the identical UHA and DHA sequences on pWHU2653 and the S. rimosus M527 chromosome where homologous recombination can take place. B. PCR verification of the mutant S. rimosus M527- nnsdAsr. M: DL10000 DNA Marker. Lane 1, PCR products of nsdAsr gene were amplified by using the primers P9/P10 from wild-type strain S. rimosus M527; lane 2, PCR products of nsdAsr gene were amplified by using the primers P9/P10 from mutant M527- $\Delta$ nsdAsr; lane 3, PCR product amplified from the wild-type S. rimosus M527 by using the primers P5/P8; lane 4, PCR product amplified from the mutant S. rimosus M527- $\Delta$ nsdAsr by using the primers P5/P8.

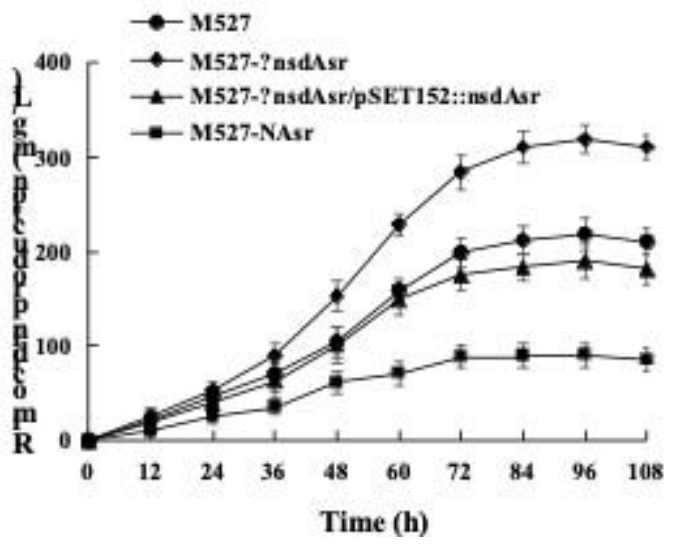


Figure 2

Determination of effects of NsdAsr on rimocidin production. Rimocidin production of the wild-type strain

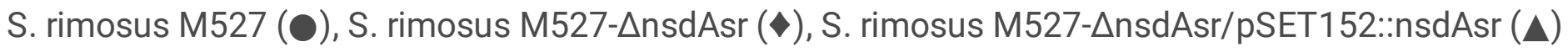
and S. rimosus M527-NAsr ( $\square$ ) in shake-flask cultures. All shake-flask fermentations were carried out in $250 \mathrm{~mL}$ flasks with a working volume of $40 \mathrm{~mL}$ at $200 \mathrm{rpm}$ and $28^{\circ} \mathrm{C}$. The medium was inoculated at $5 \%$ $(\mathrm{v} / \mathrm{v})$. The error bars were calculated from three different batches of fermentation.

A

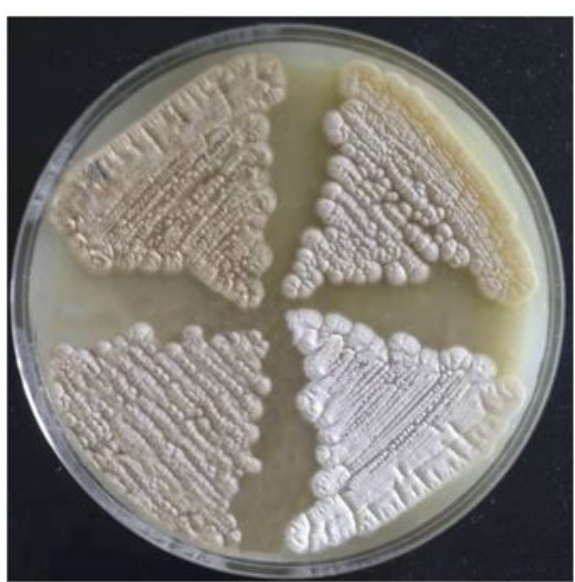

B

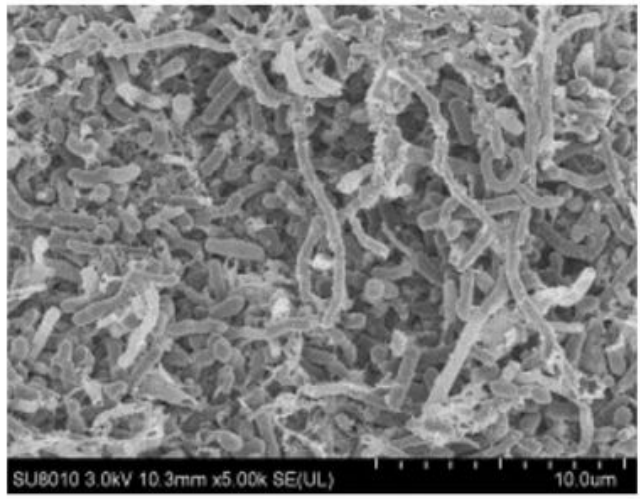

S. rimosus M527

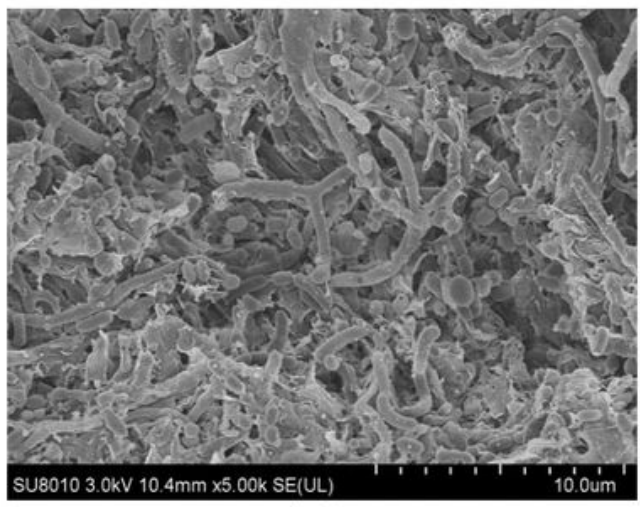

M527-AnsdAw/pSET152:-̈nsdAst
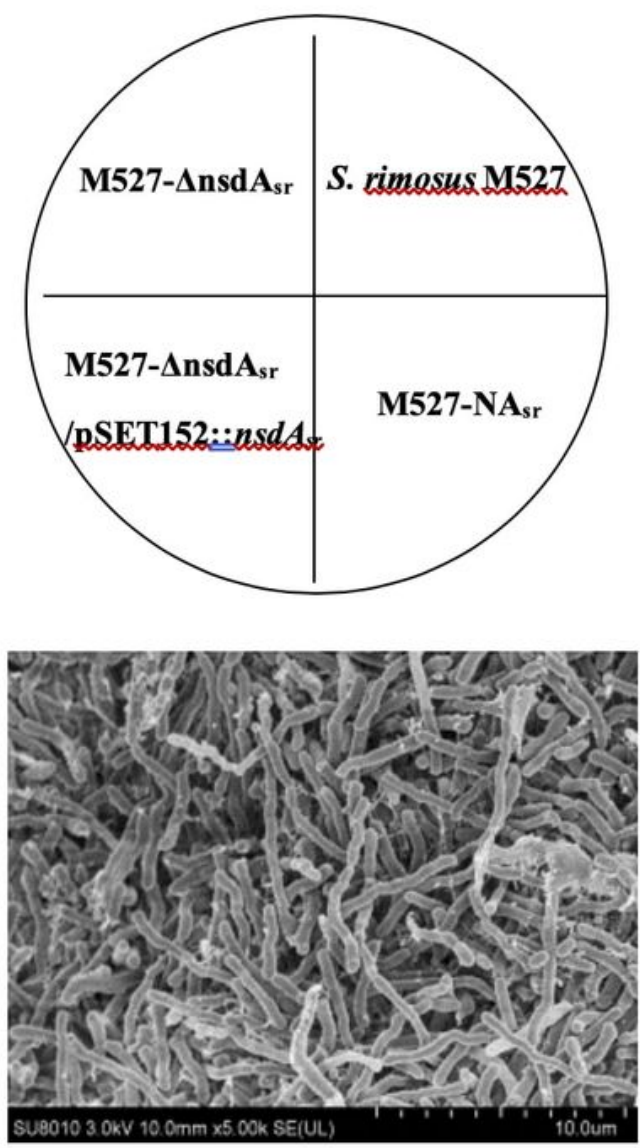

M527-AnsdA $_{\text {sr }}$

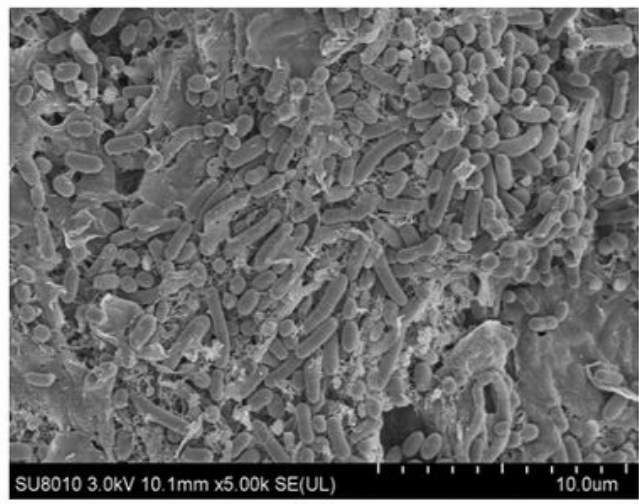

M527-NAsr $_{\text {st }}$ 


\section{Figure 3}

NsdAsr negatively affected on morphological differentiation. Morphological characteristics of the wildtype strain S. rimosus M527, S. rimosus M527-AnsdAsr, S. rimosus M527-AnsdAsr/pSET152::nsdAsr, and S. rimosus M527-NAsr. A. Picture of an agar plate taken after 7 days of growth. B. Scanning electron micrographs SEM of four strains grown on MS medium for 7 days.
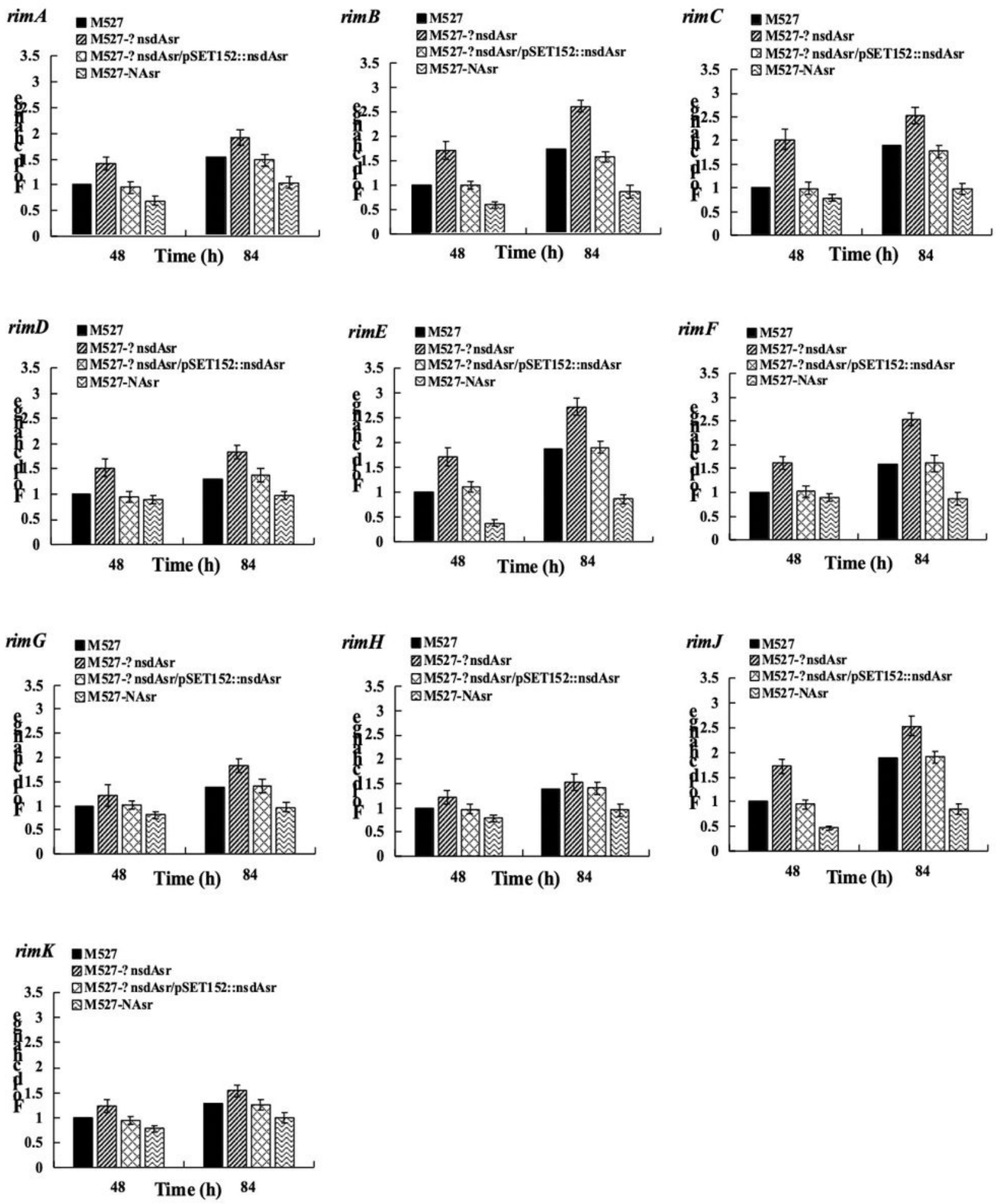

Figure 4 
Summary of qRT-PCR analysis using rim genes (rimA rimK) involved in rimocidin biosynthesis. The following strains were investigates: M527: S. rimosus M527; M527- $\Delta$ nsdAsr: S. rimosus M527- $\Delta$ nsdAsr; M527- $\Delta$ nsdAsr/pSET152::nsdAsr: S. rimosus M527- $\Delta$ nsdAsr/pSET 152::nsdAsr and M527-NAsr: S. rimosus M527-NAsr. SigBsr was used as an internal control. The cells were harvested from the fermentation broth after 48 and $84 \mathrm{~h}$. Error bars were calculated by measuring the standard deviations of the data from three replicates of each sample. $\left(^{*}\right)$ indicates statistically significant results $(0.01<P$ value $<0.05)$. ( $\left.{ }^{\star *}\right)$ indicates highly statistically significant results (P-value $\left.<0.01\right)$. rimA: type I polyketide synthase gene; rimB: type I polyketide synthase gene; rimC: tyrosine phosphatase gene; rimD: cholesterol oxidase gene; rimE: glycosyl transferase gene; rimF: aminotransferase gene; rimG: cytochrome P450 monooxygenase gene; rimH: ferredoxin gene; rim J: crotonyl-CoA reductase gene; rimK: acetyltransferase gene. 


\section{A}

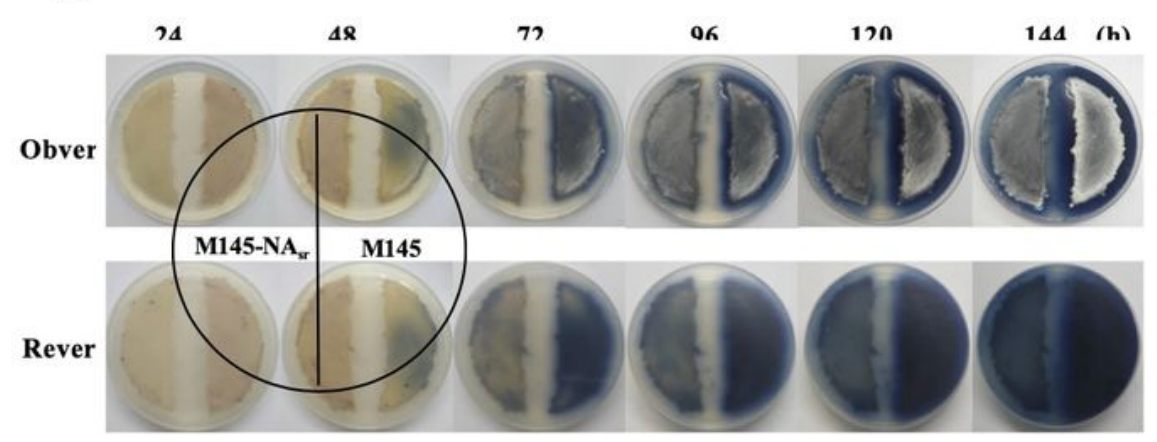

B

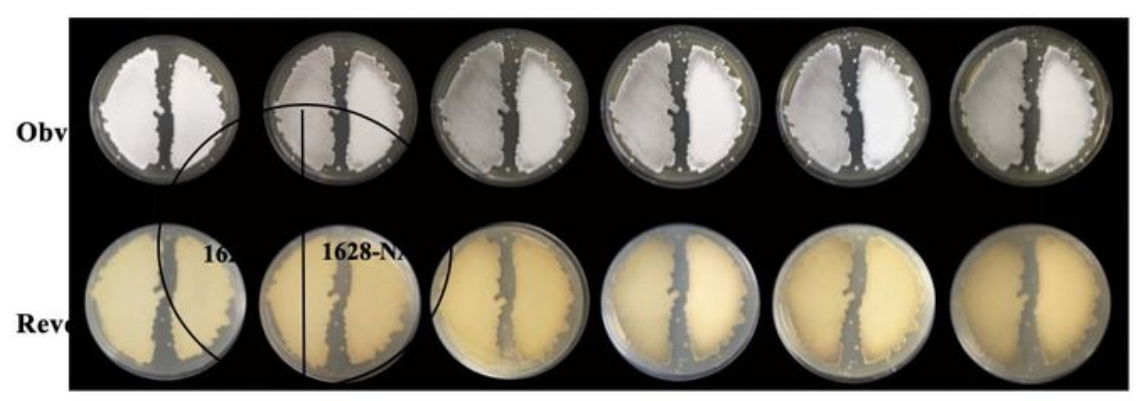

C

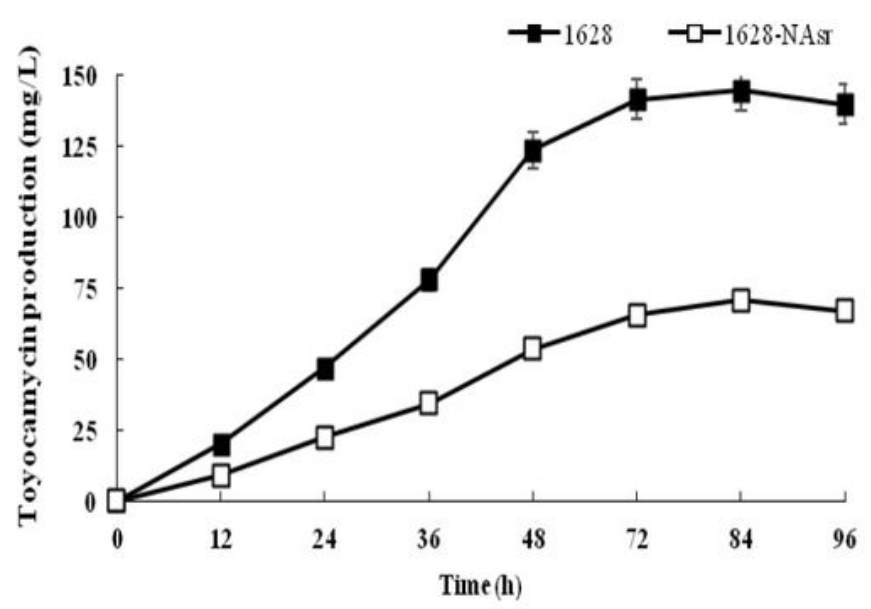

\section{Figure 5}

Heterologous expression of nsdAsr in S. coelicolor M145 and S. diastatochromogenes 1628 and its effects. A. Visual observation of morphological differentiation and Act biosynthesis by S. coelicolor M145 and S. coelicolor M145-NAsr grown on the Gauze's No.1 media. Spores $(1 \times 108)$ were streaked on Gauze's No.1 agar media and then incubated at $28^{\circ} \mathrm{C}$ for 6 days. The reverse sides of the plates are shown to indicate the amount of Act produced. B. Detection of morphological differentiation of S. 
diastatochromogenes 1628 and S. diastatochromogenes 1628-NAsr. Spores $(1 \times 108)$ were streaked on MS agar media and then incubated at $28^{\circ} \mathrm{C}$ for 6 days. C. Detection of TM production of S.

diastatochromogenes 1628 and S. diastatochromogenes 1628-NAsr in shake-flask cultures. All shakeflask fermentations were carried out in $250 \mathrm{~mL}$ flasks with a working volume of $40 \mathrm{~mL}$ at $200 \mathrm{rpm}$ and $28^{\circ} \mathrm{C}$. The medium was inoculated at $5 \%(\mathrm{v} / \mathrm{v})$. Error bars were calculated from three different batches of fermentation.

A

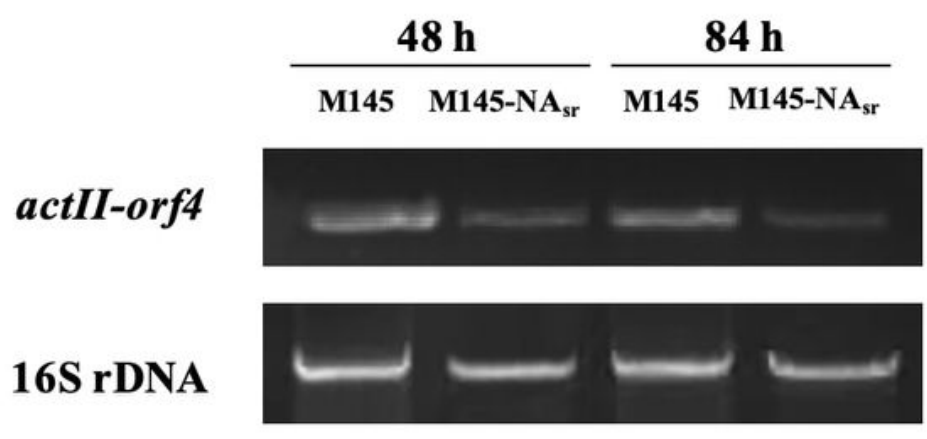

B

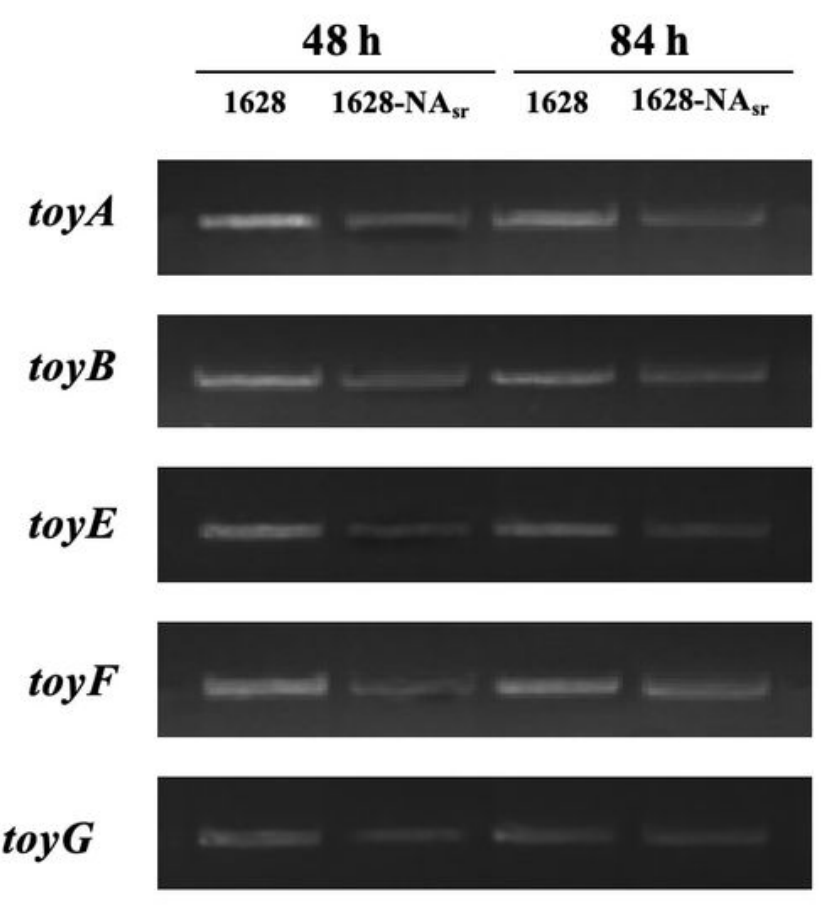

16S rDNA

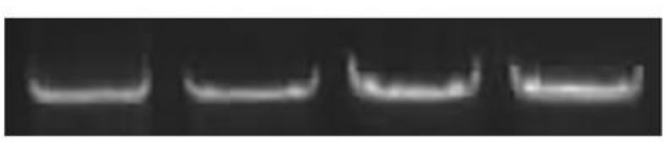

Figure 6 
Summary of qRT-PCR analysis. A. Studies on the regulator actll-orf4 are shown. Here the following strains were investigates: M145: S. coelicolor M145; M145-NAsr: S. coelicolor M145-NAsr. B. Studies on toy genes (toyA toyM) involved in TM biosynthesis are shown. Here the following strains were investigates: 1628: S. diastatochromogenes 1628; 1628-NAsr: S. diastatochromogenes 1628-NAsr. 16S rDNA was used as the positive internal control. Cells were harvested from fermentation broth at 48 and $84 \mathrm{~h}$, respectively.

\section{Supplementary Files}

This is a list of supplementary files associated with this preprint. Click to download.

- Additionalfile2.docx

- Additionalfile6.docx

- Additionalfile7.docx

- Additionalfile4.docx

- Additionalfile5.docx

- Additionalfile1.docx

- Additionalfile3.docx 